\title{
Relationshin between Cornorate Governance and Financial Performance in Multi-Purpose Co-Operative Societies, Lagos, Nigeria
}

\author{
Article by Akinade, Simeon Adebisi \\ Phd Management, Texila American University, Nigeria \\ E-mail:akinbis@yahoo.com
}

\begin{abstract}
In the light of corporate financial scandals, there is an ever increasing attention on corporate governance issues. As the investors look for emerging economies to diversify their investment portfolios to maximize returns, they are equally concerned about governance factors to minimize risks in these economies. The Government of Nigeria and other stakeholders have therefore directed their effort in enhancing Corporate Governance in various organizations. This became the motivation of this study, which is focused on examining the relationship between Corporate Governance and Financial Performance of multipurpose Cooperative Societies in Lagos State Nigeria. A cross sectional research design was used for the research study, with the aid of secondary data. The purposive sampling techniques were adopted for the study. Two (2) multipurpose Cooperative Societies were selected based on the availability of their financial statements. The data obtained were analyzed using the STATA software. From the analyses, it was established that, Corporate Governance has no significant effect on the financial performance of these multipurpose Cooperative Societies. However, it impacted positively on diligence of procedures, records kept and conduct of daily business. The researcher however opined that the radical improvement noticed in the level of governance and financial ethics introduced by the various regulatory authorities should be maintained at all levels of stewardship in organizations.
\end{abstract}

\section{Introduction}

A well performing and credible capital markets is a precondition for the development and sustainability of a vivacious private enterprise sector. And the principal policy objective is to make sure that corporations get access to the capital they need for innovation, job creation and growth. For this to happen markets need to have a healthy framework of corporate governance rules and regulations that provides investors with assurance in the system and entrepreneurs with the incentives to develop their businesses. To ensure a proficient link between finance and enterprise is particularly important in the aftermath of the financial crisis when policy makers are looking for reforms to unleash innovation and productivity for sustainable growth. It is also essential for many developing and emerging markets where new generations of enterprises should be given the opportunity to access external capital, which will make it possible for them to realize their full potential and contribution to economic growth (Karl H. 2012). (20)

Corporate governance has been in the center of debate for a long time now since the problem of principal-agent relationship had been established. According to them, the need to separate ownership and control of organizations brought with it a conflict of interests of that of the shareholders and the managers who are in charge of the organizations activities. Researchers have however been carried out to reduce if not resolve these conflicts [2]. According to Sekhar (n.d), at the height of every financial crisis, more attention is given to corporate governance in order to increase investment by enhancing investor's confidence [31]. The 2008 financial scandals in Lehman, World COM, Enron, among others made room for the interest of policy makers, regulatory bodies, researchers and other stakeholders on the quality of corporate governance in existence in organizations, as it is meant to describe the form of responsibilities of the organization's stakeholders [4], and most importantly, determine best codes of practices that will ensure firms continuous existence and inform better company performance. In any organization, 
especially the cooperative society, the management committee is in place to monitor the activities of the trustees, this function they achieve by appraising trustees proposals, approve same and also serve as a check for the achievement of effective and efficient governance practices in the cooperative society.

There is a related strand of the literature that considers corporate board characteristics as important determinants of corporate governance: board independence [8]. The question posed by Bhajat \& Bolton (2008) was if a single variable board characteristic can effectively measure corporate governance compared with those that adopted 24 or 52 variables. Their response to this was positive. They pointed out that corporate boards have the power to make, or ratify, all decisions taken within the organization and that it is likely that board members with the right volume of stock will have what it takes to provide effective supervision. With this they concluded that board independence or ownership can be a good proxy for overall good governance. In addition, the error with measuring variables will be lower with one variable than with the adoption of more variables [9].

Adu (2014) informed that cooperatives stand as an alternative in the economy, formed with the motive of a group factor of achieving what is unachievable individually [1]. Cooperative Societies around the world and most especially in Africa were brought into existence relying solely on voluntary relationship of people with the same ideology and goal on a "one-individual-one-vote basis", with the main aim of serving their needs [11].

Despite the above, cooperative societies have not been very popular in Nigeria, according to (Adu, 2014) until recently when workers cooperatives began to have a strong footing in the country. Before now, cooperatives were seen as a strategy for local farmers and sellers to better their lots [1].

Cooperative societies have operated for this long period with little attention paid to its existence. It was also discovered that members have little knowledge of what it entails - its strengths and abilities. The government had also paid "lip service" attention. The society had gone through 'thick and thin' especially in the developing countries [13]. Mutunga (2009) in her thesis identified problems of governance in cooperative societies to include the following among others: mismanagement of funds, dearth of transparency and accountability, corruption, lack of respect for the rule of law as the system encourages insider trading, which hampers corporate governance and economic performance [24]. The study was therefore carried out to investigate the relationship between corporate governance and cooperative society's performance. It also examined the quality of corporate governance practices on the financial performance of multipurpose cooperative societies in Nigeria. Management committee members, audit committee members, and trustee members (as board of directors) were adopted as variables to measure corporate governance, while the society's return on assets (ROA) was used to measure performance.

The following hypotheses were therefore stated:

1. $\mathrm{H}_{\mathrm{O}}$ : The structure of the trustee, management committee and the supervisory audit committee does not have significant effect on the society's return on assets.

2. $\mathrm{H}_{\mathrm{O}}$ : The structure of the trustee, management committee and the supervisory audit committee does not have significant effect on the society's return on equity.

\section{Literature review}

Cooperative society is a business organization registered with the intention to further the mutual benefit of the owners. These people work together with the intention of achieving as a group what they cannot attain individually. The purpose of their coming together is to provide greater benefits to the members such as increasing individual income or enhancing a member's way of living by making provision for important services that will better their lots. The main thing that separates cooperatives from other businesses is its dual capacity that is; they are business entities based on a "membership-owned model" and also have the associate aspect of pursuing social goals of its members. As such, co-operatives form an integral part of the private sector, pursuing successful commercial business practices based on the values of self-help, self-responsibility, solidarity, and democracy. In relation to other enterprise structures, co-operatives are an alternate way of doing business but at equally profitable levels. 
Co-operative activities are governed and managed by elected committee members. These people are vested with the power to manage the resources of the shareholders of which they are also part and run the daily business transactions of the society. This they achieve by delegating responsibilities to the societies' staff, which stand as agent of the society. The shareholders therefore demand that these staff be efficient, effective, responsible, honest, diligent, and prudent among others [16].

In the management of co-operatives, there has been an overlap of duties between the management committee and management staff. This reflects poor leadership and non-adherence to good management practices. For co-operatives to be efficient and productive, they should apply good corporate governance practices framed on the pillars of accountability, efficiency and effectiveness, Probity and integrity, Responsibility, transparency and open leadership.

\section{Corporate governance}

"In the fall of 2014, the hedge fund activist and Allergan shareholder Bill Ackman became increasingly frustrated with Allergan's board of directors. In a letter to the board, he took the directors to task for their failure to do "what you are paid $\$ 400,000$ per year to do on behalf of the Company's owners." The board's alleged failure: refusing to negotiate with Valeant Pharmaceuticals about its unsolicited bid to take over Allergan - a bid that Ackman himself had helped engineer in a novel alliance between a hedge fund and a would-be acquirer. In presentations promoting the deal, Ackman praised Valeant for its shareholder-friendly capital allocation, its shareholder-aligned executive compensation, and its avoidance of risky early-stage research. Using the same approach at Allergan, he told analysts, would create significant value for its shareholders. He cited Valeant's plan to cut Allergan's research budget by $90 \%$ as "really the opportunity." Valeant CEO Mike Pearson assured analysts that "all we care about is shareholder value."

These events demonstrate a way of philosophy about the governance and management of companies that is now persistence in the financial community and much of the business world. It focused on the idea that management's objective is, or should be, maximizing value for shareholders, but it addresses a ample range of topics - from performance measurement and executive compensation to shareholder rights, the role of directors, and corporate responsibility. This thought system has been embraced not only by hedge fund activists like Ackman but also by institutional investors more generally, along with many boards, managers, lawyers, academics, and even some regulators and lawmakers. Indeed, its precepts have come to be broadly regarded as a model for "good governance" and for the brand of investor activism illustrated by the Allergan story. Joseph \& Lynn (2012)

Corporate governance is viewed according to Deakin \& Hughes (1997) as the relationship between the type of governance the organization practice and what the people's opinion is concerning the issue [9]. Metrick and Ishii (2002) on the other hand viewed it as the promise made to pay a considerable amount on investment and the determination to run the organization fairly [21].

According to Mayer (1988), corporate governance is concerned with ways of bringing the interest of investors and managers into line and ensuring that firms are run for the benefit of investors [20]. Until now little attention has been paid to the governance needs of other institutional forms of business such as cooperatives despite their considerable presence in many developing countries. The cooperative sector as a whole remains poorly understood and its specific governance challenges remain as yet largely unexplored.

The term corporate governance has been used in many different ways and the boundaries of the subject vary widely. In the economics discus concerning the impact of corporate governance on performance, there are basically two different models of the corporation, the shareholder model and the stakeholder model. In its narrowest sense (shareholder model), corporate governance often describes the formal system of accountability of senior management to shareholders. In its widest sense (stakeholder model), corporate governance can be used to describe the network of formal and informal relations involving the corporation. More recently, the stakeholder approach emphasizes contributions by stakeholders that can 
DOI: $10.21522 /$ TIJMG.2015.03.02.Art016

ISSN: $2520-310 \mathrm{X}$

contribute to the long term performance of the firm and shareholder value, and the shareholder approach also recognizes that business ethics and stakeholder relations can also have an impact on the standing and long term success of the corporation. Therefore, the difference between these two models is not as stark as it first seems, and it is instead a question of emphasis.

The lack of any agreement regarding the definition of corporate governance is also reflected in the debate on governance reform. This lack of consensus leads to completely different analyses of the problem and to the unusually different solutions offered by participants in the reform process. Therefore, having a clear understanding of the different models can provide insights and help us to appreciate the different sides of this debate. An understanding of the issues involved can also provide the basis from which to identify good corporate governance practices and to provide policy recommendations.

\section{The shareholder model}

According to the shareholder model the objective of the firm is to maximize shareholder wealth through allocative, productive and dynamic efficiency i.e. the objective of the firm is to maximize profits. The criteria by which performance is judged in this model can simply be taken as the market value (i.e. shareholder value) of the firm. Therefore, managers and directors have an implicit obligation to guarantee that firms are run in the interests of shareholders. The underlying problem of corporate governance in this model stems from the principal-agent relationship arising from the parting of beneficial ownership and executive decision-making. It is this separation that causes the firm's behaviour to depart from the profit maximizing ideal. This happens because the interests and objectives of the principal (the investors) and the agent (the managers) differ when there is a separation of ownership and control. Since the managers are not the owners of the firm they do not tolerate the full costs, or reap the full benefits, of their actions. Therefore, although investors are interested in maximizing shareholder value, managers may have other objectives such as maximizing their salaries, growth in market share, or an attachment to particular investment projects, etc.

The principal-agent problem is also an essential element of the "incomplete contracts" view of the firm developed by Coase (1937), Jensen and Meckling (1976), Fama and Jensen (1983a,b), Williamson (1975, 1985), Aghion and Bolton (1992), and Hart (1995). This is because the principal-agent problem would not arise if it were possible to write a "complete contract". In this case, the investor and the manager would just sign a contract that specifies ex-ante what the manager does with the funds, how the returns are divided up, etc. In other words, investors could use a contract to perfectly align the interests and objectives of managers with their own. However, complete contracts are unfeasible, since it is impossible to foresee or describe all future contingencies. This incompleteness of contracts means that investors and managers will have to allocate "residual control rights" in some way, where residual control rights are the rights to make decisions in unforeseen circumstances or in circumstances not covered by the contract. Therefore, as Hart (1995) states: "Governance structures can be seen as a mechanism for making decisions that have not been specified in the initial contract."

\section{Firm performance}

Measuring performance can be said to be measuring the efficiency and effectiveness of an action [20]. The value of any firm can be seen as the benefits coming from the firm's shares by the shareholders [21].

Corporate governance according to Ehikioya (2009) has an effect on firm's performance in the sense that a good corporate governance system will result into more investment opportunities for the company, which serves as a pillar in the situation of illiquidity [9]. In management, the significance of performance is clear through the many prescriptions provided for performance enhancement. Research dedicated to governance structures and relationship with financial performance was highly dependent on accountingbased indicators. Some studies have adopted individual measurements (accounting-based or market-based measurements). Countless number of ways has been brought forward to measure financial performance and among them are measurements of performance as the level of Return on Assets (ROA), Return on 
Equity (ROE), Tobin-Q, Profit Margin (PM), Earnings Per Share (EPS) among others. Recently, special attention has been dedicated to determining the corporate governance effectiveness through different measurement of firm performance [23, 24, 25].

\section{Corporate governance and firm performance}

\section{Trustee structure}

There is a growing literature suggesting that U.S. boards of directors are ineffective. For example, Jensen (1993) argues that boards of directors are ineffective because board culture discourages conflict, the CEO determines the agenda and information given the board, there is little equity ownership by managers and non-managers on the typical board, boards are too large, and the CEO and the board chair is frequently the same person. Moreover, boards usually rely on the compensation consultants hired by the CEO, and this may lead to compensation contracts that have been optimized not for the firm, but for the CEO [16].

The relationship between top executive compensation and board composition has been examined in many prior empirical papers, with mixed findings. For example, Lambert, Larcker \& Weigelt (1993) and Boyd (1994) document a positive relation between CEO compensation and the percentage of the board composed of outside directors [19, 4], whereas Finkelstein and Hambrick (1989) find that compensation is unrelated to the percentage of outside directors on the board [12].

\section{Management committee structure}

Salami, K. A. (2011) investigated how ownership structure and existence of conflicts of interests among shareholders operating within a poor governance system, impacted on company profitability. His paper, using panel data and regression models, concluded that firms with low ownership concentration showed low firm profitability [30]. This stand was supported by Sørensen, R. J. (2007) who examined the effects of ownership dispersion on cost efficiency using empirical evidence, and concluded that corporate governance failure suggested that dispersion and indirect ownership weakened incentives to control the company, leading to agency losses and inferior performance [34].

\section{Supervisory audit committee}

Study showed that directors and audit committees that are independent of management are expected to improve the organization's reported earnings and the system of reporting. This is so because they are not subjected to issues that affect their interest and thereby reduces the capacity to monitor activities [32]. The supervisory committee is expected to be made up of independent directors who should be professionals who have knowledge and who are expected to work with other members in moving the society forward [33]. The audit committee should be seen to take care of the need of all the users of financial information. Studies carried out showed the weight audit independence has in sustaining credibility of the auditor and the process of financial reporting [34].

\section{Methodology}

The study is an exploratory research with investigation centered on a sampling of two (2) selected multipurpose cooperative societies in Lagos state, Nigeria, namely; LUTH/CMUL Multipurpose Cooperative Societies Ltd and College of Medicine, University of Lagos (CMUL) Multipurpose Cooperative Societies Ltd.

The data for the study was obtained from secondary sources. The annual reports and accounts for a period of five years (2011-2015) were analyzed. Sampling technique used for this study is judgmental that is (purposive) sampling. The two societies were deliberately chosen because of easy accessibility to their annual reports and accounts and in other to meet the time specified for the study.

The study employed a panel data analyses with the use of the STATA software to analyze the data gathered from both the primary and secondary sources. 
DOI: $10.21522 /$ TIJMG.2015.03.02.Art016

ISSN: $2520-310 \mathrm{X}$

The data on structure of trustee, management committee and audit committee were gotten from the annual reports and account of the societies by proxing trustee structure (Trust) with ratio of seminar expenses to total expenses, management committee structure (Mag) with ratio of Bookkeeper fee to total expenses and Supervisory audit committee (Aud) structure with ratio of audit/supervision fee to total expenses. Legal fees (Legal) which is the ratio of legal expenses to total expenses and Publicity (Pub) which is the ratio of publicity to total expenses are serving as the control variable for the study. Performance will be measured by return-on-assets ("ROA") which is the net income divided by total assets and return-on-equity (ROE) which is net income divided by Shareholder's equity while the control variable is advert and publicity. The data was estimated with panel data analysis using the STATA software package.

\section{Model specification}

$\mathrm{ROA}_{i \mathrm{t}}=\alpha_{\mathrm{it}}+\beta_{1}$ Trus $_{\mathrm{t}}+\beta_{2} \mathrm{Mag}_{\mathrm{t}}+\beta_{3} \mathrm{Aud}_{\mathrm{t}}+\beta_{4} \mathrm{Legal}_{\mathrm{t}}+\beta_{5} \mathrm{DPub}_{\mathrm{t}}+\mathrm{e}_{\mathrm{it}} \ldots \ldots$ (1)

$\mathrm{ROE}_{i t}=\alpha_{i t}+\beta_{1}$ Trus $_{t}+\beta_{2}$ Mag $_{t}+\beta_{3}$ Aud $_{t}+\beta_{4}$ Legal $_{t}+\beta_{5}$ DPub $_{t}+e_{i t} \ldots \ldots$ (2)

Where ROA and ROE represents firm performance variables which are Return on assets and Return on equity for the two cooperative societies at time $(\mathrm{t})$.

\begin{tabular}{|l|l|l|l|l|l|l|l|}
\hline crossid & year & ROA & Trus & Mag & Aud & Legal & Pub \\
\hline 1 & 2011 & 0.025473 & 0.035215 & 0.018131 & 0.008648 & 0.007499 & 0.011737 \\
\hline 1 & 2012 & 0.028299 & 0.038228 & 0.021895 & 0.010406 & 0.009583 & 0.021895 \\
\hline 1 & 2013 & 0.030023 & 0.07526 & 0.02176 & 0.008431 & 0.016863 & 0.026378 \\
\hline 1 & 2014 & 0.023386 & 0.079967 & 0.022537 & 0.014203 & 0.035064 & 0.024649 \\
\hline 1 & 2015 & 0.016799 & 0.070626 & 0.020634 & 0.020155 & 0.024676 & 0.025537 \\
\hline 2 & 2011 & 0.029554 & 0.002137 & 0.025162 & 0.010636 & 0.094238 & 0.068169 \\
\hline 2 & 2012 & 0.03915 & 0.149627 & 0.014123 & 0.014123 & 0.136339 & 0.047119 \\
\hline 2 & 2013 & 0.022899 & 0.131619 & 0.060747 & 0.010887 & 0.080996 & 0.030373 \\
\hline 2 & 2014 & 0.028248 & 0.072758 & 0.051831 & 0.016772 & 0.065154 & 0.016289 \\
\hline 2 & 2015 & 0.012824 & 0.100379 & 0.015342 & 0.019028 & 0.022874 & 0.00915 \\
\hline
\end{tabular}

Data analysis and result

Table 1. Pooled regression fixed effect random effect

\begin{tabular}{|c|c|c|c|c|c|c|}
\hline Variable & Coefficient & Std error & Coefficient & Std error & Coefficient & Std error \\
\hline Trus & $\begin{array}{l}-.0385784 \\
(0.610)\end{array}$ & .0698753 & $\begin{array}{l}-.0634876 \\
(0.408)\end{array}$ & .0661724 & $\begin{array}{l}-.0385784 \\
(0.581)\end{array}$ & .0698753 \\
\hline Mag & $\begin{array}{l}-.146668 \\
(0.346)\end{array}$ & .1374515 & $\begin{array}{l}-.0966399 \\
(0.512)\end{array}$ & -.0966399 & $\begin{array}{l}-.146668 \\
(0.286)\end{array}$ & .1374515 \\
\hline Aud & $\begin{array}{l}-1.11177 * * * \\
(0.093)\end{array}$ & .506023 & $\begin{array}{l}-.9250563 \\
(0.150)\end{array}$ & -.9250563 & $\begin{array}{l}- \\
1.11177 * * \\
(0.028)\end{array}$ & .506023 \\
\hline Legal & $\begin{array}{l}.1922738 \\
(0.165)\end{array}$ & .1134082 & $\begin{array}{l}.3025433 \\
(0.105)\end{array}$ & .3025433 & $\begin{array}{l}.1922738 * \\
* *(0.090)\end{array}$ & .1134082 \\
\hline Pub & $\begin{array}{l}-.1982445 \\
(0.477)\end{array}$ & .2531665 & $\begin{array}{l}-.3001088 \\
(0.304)\end{array}$ & -.3001088 & $\begin{array}{l}-.1982445 \\
(0.434) \\
\end{array}$ & .2531665 \\
\hline Constant & $\begin{array}{l}.0434837 * * \\
(0.021)\end{array}$ & .0118619 & $\begin{array}{l}.038942 \\
(0.041)\end{array}$ & .038942 & $\begin{array}{l}.0434837 * \\
(0.000)\end{array}$ & .0118619 \\
\hline
\end{tabular}




\begin{tabular}{|l|l|l|l|l|l|l|}
\hline R squared & 0.7311 & & & & & \\
\hline Adj R Squared & 0.3950 & & & & & \\
\hline Prob > F & 0.2357 & & 0.2019 & & & \\
\hline $\begin{array}{l}\text { Breusch and } \\
\text { Pagan } \\
\begin{array}{l}\text { Lagrangian } \\
\text { multiplier test } \\
\text { for random } \\
\text { effects }\end{array}\end{array}$ & 0.6288 & & & & & \\
\hline $\begin{array}{l}\text { hausman fixed } \\
\text { random }\end{array}$ & 0.8474 & & & & & \\
\hline Number of obs & 10 & & & & & \\
\hline
\end{tabular}

Source: Authors' Computation (2017) ***significant at 10\%** 5\%*1\% respectively

Table 2. Pooled regression fixed effect random effect

\begin{tabular}{|c|c|c|c|c|c|c|}
\hline Variable & Coefficient & Std error & Coefficient & Std error & Coefficient & $\begin{array}{l}\text { Std } \\
\text { error }\end{array}$ \\
\hline Trus & $\begin{array}{l}-.0748556 \\
(0.312)\end{array}$ & .0647205 & $\begin{array}{l}-.097272 \\
(0.217) \\
\end{array}$ & .0623308 & $\begin{array}{l}-.0078191 \\
(0.247)\end{array}$ & $\begin{array}{l}.064720 \\
5\end{array}$ \\
\hline Mag & $\begin{array}{l}-.0078191 \\
(0.954)\end{array}$ & .1273115 & $\begin{array}{l}.0372023 \\
(0.782)\end{array}$ & .1228117 & $\begin{array}{l}-.0078191 \\
(0.951)\end{array}$ & $\begin{array}{l}.127311 \\
5\end{array}$ \\
\hline Aud & $\begin{array}{l}- \\
1.023604 * * * \\
(0.094)\end{array}$ & .468693 & $\begin{array}{l}-.8555755 \\
(0.155)\end{array}$ & .4526303 & $\begin{array}{l}- \\
1.023604 * \\
*(0.029) \\
\end{array}$ & .506023 \\
\hline Legal & $\begin{array}{l}.0510439 \\
(0.652) \\
\end{array}$ & .1050419 & $\begin{array}{l}.150278 \\
(0.312) \\
\end{array}$ & .1238009 & $\begin{array}{l}.0510439 \\
(0.627) \\
\end{array}$ & $\begin{array}{l}.105041 \\
9\end{array}$ \\
\hline Pub & $\begin{array}{l}.0837655 \\
(0.739)\end{array}$ & .23449 & $\begin{array}{l}-.0079045 \\
(0.975)\end{array}$ & .2282099 & $\begin{array}{l}.0837655 \\
(0.721)\end{array}$ & .23449 \\
\hline Constant & $\begin{array}{l}.0432927 * * \\
(0.017)\end{array}$ & .0109868 & $\begin{array}{l}.0392056 \\
(0.035)\end{array}$ & .0106438 & $\begin{array}{l}.0432927 * \\
* *(0.000) \\
\end{array}$ & $\begin{array}{l}.010986 \\
8 \\
\end{array}$ \\
\hline R squared & 0.7927 & & $\begin{array}{l}0.6474 \\
\text { (overall) }\end{array}$ & & $\begin{array}{l}0.7927 \\
\text { (overall) }\end{array}$ & \\
\hline Adj R Squared & 0.5335 & & & & & \\
\hline Prob $>$ F & 0.1506 & & 0.2019 & & $0.0092 * * *$ & \\
\hline $\begin{array}{l}\text { Breusch and Pagan } \\
\text { Lagrangian multiplier } \\
\text { test for random } \\
\text { effects }\end{array}$ & 0.6038 & & & & & \\
\hline $\begin{array}{l}\text { hausman fixed } \\
\text { random }\end{array}$ & 0.8756 & & & & & \\
\hline Number of obs & 10 & & 10 & & 10 & \\
\hline
\end{tabular}

Source: Authors' Computation (2017)***significant at 10\%**5\%*1\% respectively

The panel result is as shown in Table 1 and 2. The regression equation employed ROA as its dependent variable in Table 1 and Trustee structure, Management committee structure, Supervisory audit structure, Legal fees and Advert/Publicity fees as independent variables. Legal fees and advert/publicity fees are control variables. 
DOI: $10.21522 /$ TIJMG.2015.03.02.Art016

ISSN: $2520-310 \mathrm{X}$

The result showed that the structure of supervisory audit committee is significant in explaining the effect of corporate performance in terms of ROA for pooled regression and Random effect while not significant for fixed effect. The R-squared further clarifies it by indicating that about $73 \%$ of the variation in ROA is accounted for by these independent variables. The control variable (legal fees) and Advert/publicity fees indicated that a percent increase in legal fees has a positive $19 \%$ increase effect on ROA while Advert/publicity has a negative influence on ROA. This shows that the higher the legal fees the higher the returns on assets. The hausman fixed random test further emphasized the acceptance of random effect when fixed effect is not relevant. For return on equity, it is also the audit independence that is significant but in comparison with the ROA showed that an increase in supervisory audit committee will reduce ROE by $102 \%$ while both the control variables have a positive effect on ROE.

The model is as follows:

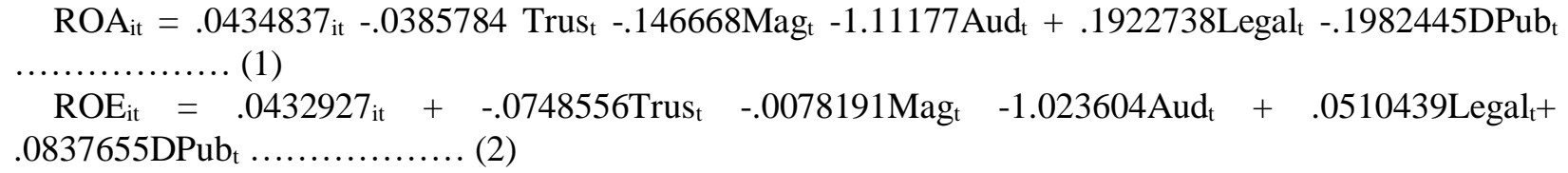

\section{Summary of finding, conclusion and recommendation}

From the analyses, it was established that Corporate Governance has no significant effect on the financial performance of these multipurpose Corporative Societies. This made the researcher conclude that there is no relationship between Corporate Governance and Financial Performance. However, recommendations are made as follow; corporate governance framework should be continuously strengthened through amendments to securities and companies laws and regulations. Whistle blowing provisions should be introduced, where external auditors "e have a mandatory requirement for whistle blowing sanity most likely will prevail. This has been very effective in highlighting problems in PLCs and the auditors have taken their role very seriously in this regard.

Other aspects included introducing qualifications for directors and strengthening the role of audit committees. The Securities Commission's enforcement powers should also be widened, not just too criminal actions but also for civil remedies, restitution abilities and administrative actions, includes requiring a restatement of PLC accounts if the Commission is of the view that they were not prepared in accordance with accounting standards. Furthermore, prominent issue is a tradition of heavy dependence on regulatory discipline. While regulatory discipline is important, it is no substitute for the need for companies to govern themselves responsibly. The challenge ultimately is to internalise a culture of good governance in companies, and for them to recognise the value that good governance provides beyond mere box ticking. Corporate governance should be approached in the context of three disciplines: regulatory discipline, self-discipline and market discipline. Investors should regularly communicate to the industry that there should be less reliance on regulatory discipline and place more emphasis on self- and market discipline mechanisms.

Finaly, the radical improvement noticed in the level of governance and financial ethics introduced by the various regulatory authorities should be maintained at all levels of stewardship in organizations.

\section{References}

[1].Adu, C. A. (2014). Cooperative societies in Nigeria: prospects and problems. International Journal of Behavioral Social and Movement Sciences, 3(3).

[2].Aguilera, R. V., \& Jackson, G. (2003). The cross-national diversity of corporate governance: Dimensions and determinants. The Academy of Management Review, 447-465.

[3].Bhagat, S., Bolton, B. J., Romano, R., (2007). The promise and peril of corporate governance indices. ECGI Law Working Paper No. 89/2007.

[4].Boyd, B.K. (1994). Board control and CEO compensation. Strategic Management Journal 15. 
[5].Bozec, R., Dia, M., \& Bozec, Y. (2010). Governance - performance relationship: A re-examination using technical efficiency measures. British Journal of Management, 21, 684-700. http://dx.doi.org/10.1111/j.14678551.2008 .00624$.

[6].Brasilia (2008).Corporate governance: Guidelines for Good Practices of Financial Cooperative Governance.

[7].Brennan, N. (2006). Boards of directors and firm performance: Is there expectations gap/Corporate governance: An International Review, 14(6), 577-593.

[8].Bye-Laws 2003.

[9].Deakin \& Hughes (1997).

[10]. Ehikioya, B. (2009). Corporate governance structure and firm performance in developing economies: evidence from Nigeria. Q Emerald Group Publishing Limited, 9(3), 231-243. http://dx.doi.org/10.1108/14720700910964307.

[11]. Fama, E., \& Jensen, M. (1983). Separation of ownership and control, Journal of Law and Economics, 301-326.

[12]. Finkelstein, S., Hambrick, D., 1989. Chief executive Compensation: a study of the intersection of markets and political processes. Strategic Management Journal 10, 121-134.

[13]. García-Sánchez, I. M. (2010). The effectiveness of corporate governance: board structure and business technical efficiency in Spain. CEJOR, 18, 311-339. http://dx.doi.org/10.1007/s10100-009-0112-4.

[14]. Hermalins, B. E. and Weisbach, M. S. (2003). Boards of directors as an endogenously determined institution: A survey of the economic literature, Economic Policy Review 9(1), 7-26.

[15]. Islam, M. Z., Islam, M. N., Bhattacharjee, S., \& Islam, A. Z. (2009). Agency problem and the role of audit committee: Implications for corporate sector in Bangladesh. International Journal of Economics and Finance, 2(3), 177.

[16]. Jensen, M., Meckling, W. (1976). Theory of the firm: managerial behavior, agency costs, and ownership structure. Journal of Financial Economics 3, 305-360.

[17]. Jensen, M. (1993). The modern industrial revolution, exit, and the failure of internal control systems. Journal of Finance 48, 831-880.

[18]. Jonsson, F.I. (2005). The role model of the board: A preliminary study of the roles of Iceland board. Corporate governance: An International Review, 13(5), 710-717.

[19]. Lambert, R., Larcker, D., Weigelt, K. (1993). The structure of organizational incentives. Administrative Science Quarterly 38, 438-461.

[20]. Maria M., Thomas A. Corporate governance: effects on firm performance and economic growth.1999. Pg 5-7.

[21]. Mayer, C. (1997). New issues in corporate governance. European Economic. Review 32, 1167-1188.

[22]. Metrick and Ishii (2002).

[23]. Muamba, G. M. (2005). An assessment of the impact of co-operative society loan to small scale and medium enterprises in Kenya. Research Thesis, Jomo Kenyatta University, Nairobi.

[24]. Mudibo, E. k. (2005). Corporate governance in co-operatives, the east Africa.

[25]. Mutunga E.K. (2009).Study of corporate governance practices and challenges by co-operative societies in NAIROBI (A study of selected Co-operative Societies in Nairobi.

[26]. Neely, A., Gregory, M., \& Platts, K. (2005). Performance measurement system design: A literature review and research agenda. International Journal of Operations \& Production Management, 25(12), 1128-1263.

[27]. Nguyen, B. D., \& Nielsen, K. M. (2010). The value of independent directors: Evidence from sudden deaths. Journal of Financial Economics, 98(3), 550-567.

[28]. O’Sullivan, A., \& Sheffrin S.M. (2003). Economics: Principles in action .Upper Saddle River, New Jersey, Pearson. Prentice Hall.

[29]. Proceedings Report, 2007.

[30]. Rouf, M. A. (2011). The relationship between corporate governance and value of the firm in developing countries: Evidence from Bangladesh. The International Journal of Applied Economics and Finance, 5(3), 237-244.

[31]. Salami, K. A. (2011). Analysis of the relationship between share ownership structure, corporate governance structure, and corporate investment efficiency, using GSE Market Data (2005-9). Journal of Accounting and Finance, 11(4), 111-118. 
DOI: $10.21522 /$ TIJMG.2015.03.02.Art016

ISSN: $2520-310 \mathrm{X}$

[32]. Sekhar, M. A. (n.d). Corporate governance and firms 'financial performance. Journal of Academic and Business Ethics.

[33]. Sheu, H., \& Yang, C. (2005). Insider ownership structure and firm performance: A productivity perspective study in Taiwan's electronics industry. Corporate Governance, 13(2), 326-337.

[34]. Siagian, F. T., \& Tresnaningsih, E. (2011). The impact of independent directors and independent audit committees on earnings quality reported by Indonesian firms. Asian Review of Accounting, 19(3), 192-207.

[35]. Sørensen, R. J. (2007). Does dispersed public ownership impair efficiency? The case of refuse collection in Norway. Public administration, 85(4), 1045-1058.

[36]. https://hbr.org/2013/11/what-weve-learned-from-the-financial-crisis. 